\title{
PERBANDINGAN KOMPRES AIR HANGAT DENGAN KOMPRES AIR JAHE TERHADAP LOW BACK PAIN PADA LANSIA DI RUMAH USIAWAN PANTI SURYA SURABAYA
}

\author{
Aristina Halawa* Timotius Brillian Marcelino Ardianto** \\ STIKES William Booth Surabaya Jl. Cimanuk No.20 Email: halawaaristina@yahoo.co.id
}

\begin{abstract}
ABSTRAK
Lansia banyak mengalami kemunduran baik secara fisik maupun psikologis. Kemunduran fisik yang terjadi salah satunya ialah low back pain. Low back pain bila tidak diatasi dengan baik maka akan mengakibatkan pergerakkan tubuh pada lansia terbatas. Penanganan dalam mengatasi nyeri akibat low back pain salah satunya ialah dengan kompres hangat dan kompres jahe. Penelitian ini bertujuan untuk mengetahui perbandingan kompres hangat dan kompres jahe terhadap low back pain pada lansia di Rumah Usiawan Panti Surya Surabaya. Desain penelitian ini iala komparasi. Populasi penelitian ini ialah 18 responden lansia yang mengeluh low back pain dengan sampel 10 responden yang dibagi menjadi 2 kelompok yaitu 5 responden pada kelompok pemberian kompres air hangat dan 5 responden pada kelompok pemberian kompres air jahe, dengan teknik pengambilan sampel probability sampling. Pengumpulan data menggunakan lembar observasi sebelum dan sesudah pemberian kompres air hangat dan kompres air jahe. Hasil penelitian menunjukkan bahwa mayoritas responden yang diberikan kompres air jahe mengalami penurunan skala nyeri low back pain sebanyak 5 responden dan kelompok yang diberikan kompres air hangat mayoritas mengalami penurunan skala nyeri sebanyak 4 responden. Analisa data menggunakan uji statistik Mann Whitney dengan nilai $\mathrm{p}<0.05$ didapatkan $\mathrm{p}=0.05$ berarti tidak perbedaan pemberian kompres air hangat dengan kompres air jahe terhadap penurunan skala nyeri pada lansia dengan low back pain di Rumah Usiawan Panti Surya Surabaya. Meskipun hasil uji statistic menunjukkan tidak ada perbedaan tetapi bila dilihat pada hasil penelitian menunjukkan ada perbedaan yang signifikan pada pemberian kompres jahe dibanding kompres hangat. Hal ini disebabkan karena jahe memiliki kandungan yang bermanfaat sebagai analgesic, anti inflamasi dan anti oksidan.
\end{abstract}

Kata Kunci : low back pain, lansia, kompres hangat, kompres jahe, skala nyeri

\begin{abstract}
Elderly people experience many setbacks both physically and psychologically. Physical deterioration that occurs is one of them is low back pain. Low back pain if it is not handled well it will result in limited body movement in the elderly. Handling in dealing with pain due to low back pain one of them is by warm compresses and ginger compresses. This study aims to determine the ratio of warm compresses and ginger compresses to low back pain in the elderly at the Home of Usiawan Panti Surya Surabaya. The design of this study is a comparative design. The population of this study was 18 elderly respondents who complained of low back pain with a sample of 10 respondents divided into 2 groups, 5 respondents in the group giving warm water compresses and 5 respondents in the group giving ginger water, with probability sampling sampling technique. Data collection used observation sheets before and after giving warm water compresses and ginger water compresses. The results showed that the majority of respondents who were given ginger water compressions decreased the scale of low back pain pain by 5 respondents and the group that was given warm water compresses had a majority decrease in pain scale by 4 respondents. Data analysis using Mann Whitney statistical test with $\mathrm{p}$ value $<0.05$ obtained $\mathrm{p}=0.05$ means that there is no difference in the provision of warm water compresses with ginger water compresses to decrease the scale of pain in the elderly with low back pain at the Usiawan Panti Surya Surabaya Home. Although the results of the statistical tests showed no difference, but when viewed from the results of the study, there were significant differences in the administration of ginger compresses compared to warm compresses. This is because ginger has a content that is useful as an analgesic, anti-inflammatory and anti-oxidant.
\end{abstract}

Keywords: low back pain, elderly, warm compresses, ginger compresses, pain scale 


\section{PENDAHULUAN}

Lansia merupakan salah satu kelompok penduduk yang potensial menjadi masyarakat rentan, oleh karena itu kondisi non fisik maupun fisik perlu diciptkan supaya kondusif agar kesejahteraanya terbina. Indonesia dan beberapa Negara lainnya bukan hanya mengharapkan lansia berumur panjang, namun lansia juga dapat berguna untuk pembangunan dalam masa tuanya. (Hutapea, 2005). Lansia adalah proses alami dan menjadi tua pasti dialamioleh semua orang. Pada masa tua tidak dapat dihindari adanya kemunduran fisik, sosial dan mental secara bertahap akan dialami seseorang yang menjadi tua (Azizah 2011). Low Back Pain adalah ssalah satu keluahan yang sering dialami oleh lansia (Bandiyah, 2009). Low Back Pain (LBP) keadaan patologik pada bagian pinggang atau dekat pinggang yang dialami oleh jaringan atau alat tubuh yang merupakan bagian pinggang atau yang ada di dekat pinggang. (Idyan, 2007). Semua usia apakah muda ataupun lansia dapat mengalami keluhan LBP (Hendri, 2014). Seseorang yang mengeluh LBP dapat menurunkan produktivitasnya karena mengalami nyeri. Di Negara Industri 80\% penduduknya pernah menderita LBP dan persentasenya akan terus meningkat sesuai dengan pertambahan usia (Ginting, 2010). Low Back Pain (LBP) apabila tidak ditangani dapat tidak hanya menyebabkan nyeri, frustasi dan distress tetapi juga dapat menjadi kaku sekujur tubuh yang berujung tidak bisa berjalan atau menggerakkan tubuhnya yang mengakibatkan cacat seumur hidup pada lansia (Mujianto, 2013). Nyeri merupakan sensasi yang tidak menyenangkan yang terjadi jika mengalami cedera ataupun kerusakan pada tubuh. Keluhan nyeri dapat terasa seperti rasa panas, kesemutan/tertusuk, dan ditikam. Nyeri akan menjadi suatu masalah gangguan kesehatan dikarenakan dapat menganggu aktivitas yang akan dilakukan dan ketidaknyamanan yang berkepanjangan (Mujianto, 2013).

Berdasarkan survey awal penulis di panti werdha yang di Surabaya yang mengalami nyeri punggung yang belum diatasi dengan baik yang tidak bisa beraktivitas karena tidak mampu menahan nyeri bahkan sampai mengalami bungkuk kedepan atau kifosis. Hal ini dibuktikan dengan seringnya lansia yang ditemui oleh penulis mengeluh nyeri pada punggung bawah (Low Back Pain) yang biasanya ditangani hanya menggunakan pengobatan farmakologis saja. Pengobatan Farmakologis oleh lansia dinilai kurang efektif karena Low Back Pain yang diderita lansia dapat timbul kembali yang menyebabkan lansia harus mengonsumsi obat, bila hal ini terus dilakukan dalam jangka panjang tentu akan megakibatkan kerusakan organ tubuh. Kompres pada area nyeri dipercaya dapat menurunkan tingkat nyeri yang dialami. Banyak jenis kompres untuk mengurangi nyeri antara lain ialah kompres air hangat dan kompres air jahe hangat. Dody Setyawan (2014) dalam jurnal penelitian dengan judul pengaruh pemberian kompres hangat pada leher terhadap penurunan intensitas nyeri kepala pada pasien hipertensi di RSUD Tugurejo Semarang, Disimpulkan bahwa kompres air hangat bekerja dengan merelaksasikan otot yang nyeri sedangkan dalam jurnal penelitian, Syiddatul (2017) kompres air jahe hangat bekerja dengan memperlancar sirkulasi darah karena jahe mengandung gingerol dan mempunyai sensasi rasa hangat. Berdasarkan apa yang penulis baca dari beberapa jurnal, kompres air hangat dan kompres air jahe efektif lebih menurunkan nyeri yang ditimbulkan oleh low back pain sehingga penulis ingin membandingkan efektifitas kompres air hangat dengan kompres air jahe terhadap penurunan nyeri pada lansia low back pain. Kawasan Asia Tenggara sebesar 142 juta jiwa atau $8 \%$, sedangkan populasi lansia pada tahun 2050 diperkirakan meningkat 3 kali lipat dari tahun ini, Pada tahun 2000 jumlah Lansia sekitar 5,300,000 (7,4\%) dari total polulasi, sedangkan pada tahun 2010 jumlah Lansia $24,000,000 \quad(9,77 \%)$ dari total populasi, dan tahun 2020 diperkirakan jumlah Lansia mencapai 28,800,000 $(11,34 \%)$ dari total populasi. pada tahun 2020 di Indonesia sendiri diperkirakan jumlah Lansia sekitar 80.000.000 (WHO,2013). Provinsi Daerah Istimewa Yogyakarta merupakan paling tinggi memiliki penduduk lansia yaitu $(13,04 \%)$, dan Jawa Tengah $(10,34 \%)$ serta Jawa Timur (10,40\%), (Susenas BPS RI, 2012). Berdasarkan Dinas Kesehatan Kota Surabaya tahun 2010 terdapat data yang masuk sebesar 42.000 Lansia. Hampir 70\%-80\% penduduk negara maju pernah mengalaminya. LBP merupakan 
masalah kesehatan yang paling penting di semua negara. Kebanyakan Low Back Pain akut bersifat self limiting dan hanya $2-7 \%$ yang menjadi kronis (Jalaluddin, 2008). Pada studi pendahuluan didapatkan oleh penulis di panti usiawan surya didapatkan 10 responden mayoritas mengeluh nyeri berat akibat low back pain. Dari 10 responden dibagi menjadi 2 kelompok yaitu 5 responden pada kelompok pemberian kompres hangat dan 5 responden pada kelompok pemberian kompres jahe. Penulis melakukan intervensi pada 2 kelompok dan mendapatkan hasil pada kelompok kompres hangat 5 responden yang mengalami nyeri berat megalami penurunan menjadi 4 responden mengalami nyeri sedang. Sedangkan pada kelompok kompres jahe 5 responden yang menglami nyeri berat mengalami penurunan menjadi nyeri sedang sebanyak 2 responden dan nyeri ringan sebanyak 3 responden.

Salah posisi saat mengangkat beban merupakan salah satu aktivitas yang dilakukan dengan tidak benar, yang dapat menyebabkan low back pain (Rogers, 2006). Aktivitas menunduk ke depan, perut menonjol ke depan, kepala bahu melengkung ke depan, dan lordosis lumbal berlebihan dapat menyebabkan spasme otot (ketegangan otot) adalah kesalahan postur. Nyeri punggung (low back pain) tidak hanya akan menyebabkan nyeri dan ketidaknyamanan yang berkepanjangan bahkan sampai dapat mengakibatkan cacat seumur hidup seperti kifosis apabila tidak ditangani dengan tepat (Mujianto, 2013). Mobilitas lumbal menjadi terbatas, terutama untuk gerakan membungkuk (fleksi) dan memutar (rotasi) (Watson Roger, 2002). Nyeri dan spasme otot seringkali membuat individu takut menggunakan punggungnya. Lansia yang takut menggunakan punggungnya karena nyeri berakibat lansia harus menyesuaikan dirinya terhadap nyeri yaitu dengan mempertahankan posisi punggungnya yang menyebabkan lansia menjadi bungkuk. Mengakibatkan lansia mengalami masalah seperti ketergantungan pada orang lain, terbatasnya aktivitas fisik bahkan mempengaruhi psikologis lansia karena malu terhadap keadaan dirinya. Lansia yang mengalami Low Back Pain, ditangani dengan mengkonsumsi obat-obatan yang menurut lansia lebih praktis dan mudah. Namun jika sering menggunakan obat-obatan menimbulkan efek samping dan nyeri yang dialami lansia sering timbul yang akan megakibatkan biaya pengobatan lebih tinggi. Kompres dalam menangani nyeri punggung bawah sebenarnya dinilai lebih efektif dalam menghilangkan nyeri pada lansia. Namun, cara ini jarang dipakai karena kompres yang prosesnya menghabiskan waktu banyak dalam prosedurnya. Lansia yang kondisi fisiknya mengalami penurunan fisik, sehingga tidak mampu dalam membuat kompres untuk mengurangi nyeri. Kompres terbagi dalam beberapa jenis antara lain: Kompres Hangat, Kompres Hangat Kering, Kompres Dingin, Kompres Gelatine (jelly), Kompres Kimiawi (Mahir,2008). Kompres hangat adalah suatu metode dalam penggunaan suhu hangat yang dapat menimbulkan efek fisiologis (Anugraheni, 2013). Kompres air jahe adalah suatu metode kompres yang mencampurkan 5 rimpang jahe ( \pm 100 gram) yang di iris tipis-tipis dengan air 1 liter untuk menimbulkan rasa hangat biasa untuk menangani nyeri (Puspaningtyas \& Utami (2013)

Namun untuk mengatasi nyeri yang dirasakan akibat LBP dengan menggunakan metode alternatife yang digunakan perawat yaitu kompres hangat dan kompres air jahe. kompres air hangat berguna untuk menurunkan nyeri karena dapat meredakan nyeri, meningkatkan relaksasi otot, meningkatkan sirkulasi, meningkatkan relaksasi psikologis, dan memberi rasa nyaman, bekerja sebagai counterirritant (Koizier \& Erb, 2009), dan kompres jahe merupakan tindakan yang sering kali digunakan sebagai obat nyeri persendian karena kendungan gingerol dan rasa hangat yang ditimbulkannya membuat pembuluh darah terbuka dan memperlancar sirkulasi darah, sehingga suplai makanan dan oksigen lebih baik dan low back pain berkurang (Utami \& Puspaningtyas, 2013). Dari kedua metode kompres hangat dengan kompres air jahe hangat mempunyai keistimewaan yaitu bahannya mudah di dapat, murah, tidak mengandung bahan kimia, dan tidak mengandung efek samping dengan kadar yang terlalu tinggi. Menurut Puspaningtyas \& Utami (2013) Pada tahapan fisiologis nyeri, kompres jahe menurunkan low back pain pada tahap transduksi, dimana pada tahapan ini jahe memiliki kandungan gingerol yang mengandung siklooksigenase yang bisa 
menghambat terbentuknya prostaglandin sebagai mediator nyeri, sehingga terjadi penurunan nyeri pada low back pain.

\section{METODE PENELITIAN}

Subyek dalam penelitian ini adalah lansia yang mengalami low back pain yang tinggal di Rumah Usiawan Panti Surya Surabaya sebanyak 18 orang lansia. Dalam penelitian ini teknik pengambilan sampelnya adalah total sampling (Nurssalam,2016). Berdasarkan kriteria inklusi yang ditetapkan yaitu Lansia yang termasuk dalam usia lanjut 45-75 tahun. Lansia low back pain yang mampu berkomunikasi dengan lancar, mampu membaca dan menulis, bersedia menjadi responden melalui informed consent di Rumah Usiawan Panti Surya Jemur Andayani Surabaya. Variabel dalam penelitian ini adalah skala nyeri low back pain dengan kompres air hangat dan kompres jahe. Kesulitan penelitian ini ialah responden yang ada tidak diperbolehkan oleh dokter yang merawat lansia dan lansia tidak berkenan mengikuti terapi kompres air hangat dan air jahe. Tidak seluruhnya lansia diperbolehkan oleh pihak yayasan panti untuk dilakukan intervensi dikarenakan ada lansia yang berjenis kelamin perempuan yang merasa tidak nyaman bila dilakukan intervensi kompres oleh peneliti. Teknik pengolahan data menggunakan lembar observasi dengan membandingkan skala nyeri low back pain sebelum dan sesudah kompres air hangat dan kompres jahe.

\section{HASIL}

Skala nyeri lansia dengan low back pain dalam perbandingan kompres hangat dan kompres jahe terhadap penurunan skala nyeri di panti usiawan surya surabaya. Distribusi data mengenai skala nyeri sebelum dan sesudah pemberian kompres hangat dan kompres jahe.

Tabel 1 distribusi data pre test sebelum dilakukan kompres hangat dan kompres air jahe

\begin{tabular}{ccccccc}
\hline No & Skala & Juml & Pers & Skala & Ju & Pers \\
& Nyeri & ah & enta & Nyeri & ml & entas \\
& Pre tes & & se & Pre tes \\
kom & ahpre \\
kompr & & & & \\
& es & & & sair \\
& hangat & & & jahe & & \\
\hline 1 & Nyeri & - & - & Nyeri & - & - \\
\hline
\end{tabular}

\begin{tabular}{|c|c|c|c|c|c|c|}
\hline \multirow[b]{2}{*}{2} & \multicolumn{2}{|l|}{ ringan } & \multicolumn{3}{|c|}{ ringan } & \multirow[b]{2}{*}{ - } \\
\hline & $\begin{array}{l}\text { Nyeri } \\
\text { sedang }\end{array}$ & 1 & $\begin{array}{l}10 \\
\%\end{array}$ & $\begin{array}{l}\text { Nyeri } \\
\text { sedang }\end{array}$ & - & \\
\hline 3 & $\begin{array}{l}\text { Nyeri } \\
\text { berat }\end{array}$ & 4 & $\begin{array}{l}40 \\
\%\end{array}$ & $\begin{array}{l}\text { Nyeri } \\
\text { berat }\end{array}$ & 4 & $40 \%$ \\
\hline 4 & $\begin{array}{l}\text { Nyeri } \\
\text { hebat }\end{array}$ & - & - & $\begin{array}{l}\text { Nyeri } \\
\text { hebat }\end{array}$ & 1 & $10 \%$ \\
\hline & Jumlah & 5 & $\begin{array}{l}50 \\
\% \\
\end{array}$ & Jumlah & 5 & $50 \%$ \\
\hline
\end{tabular}

Berdasarkan tabel diatas, responden yang mengalami nyeri berat turun menjadi nyeri sedang sebanyak 4 responden sedangkan responden yang mengalami nyeri sedang dan tidak mengalami penurunan sebanyak 1 responden.

Tabel 2 distribusi data post test pemberian kompres hangat dan kompres air jahe

\begin{tabular}{|c|c|c|c|c|c|c|}
\hline No. & $\begin{array}{c}\text { Skala } \\
\text { Nyeri } \\
\text { Post tes } \\
\text { kompres } \\
\text { hangat } \\
\end{array}$ & $\begin{array}{c}\text { Juml } \\
\text { ah }\end{array}$ & $\begin{array}{c}\text { Pers } \\
\text { entas } \\
\text { e }\end{array}$ & $\begin{array}{c}\text { Skala } \\
\text { Nyeri } \\
\text { Post tes } \\
\text { kompres } \\
\text { air jahe }\end{array}$ & $\begin{array}{l}\text { Jum } \\
\text { lah }\end{array}$ & $\begin{array}{l}\text { per } \\
\text { sen } \\
\text { tase }\end{array}$ \\
\hline 1 & $\begin{array}{l}\text { Nyeri } \\
\text { ringan }\end{array}$ & - & - & $\begin{array}{l}\text { Nyeri } \\
\text { ringan }\end{array}$ & 3 & $\begin{array}{l}30 \\
\%\end{array}$ \\
\hline 2 & $\begin{array}{l}\text { Nyeri } \\
\text { sedang }\end{array}$ & 5 & $50 \%$ & $\begin{array}{l}\text { Nyeri } \\
\text { sedang }\end{array}$ & 2 & $\begin{array}{l}20 \\
\%\end{array}$ \\
\hline 3 & $\begin{array}{l}\text { Nyeri } \\
\text { berat }\end{array}$ & - & - & $\begin{array}{l}\text { Nyeri } \\
\text { berat }\end{array}$ & - & - \\
\hline \multirow[t]{2}{*}{4} & $\begin{array}{l}\text { Nyeri } \\
\text { Hebat }\end{array}$ & - & - & $\begin{array}{l}\text { Nyeri } \\
\text { hebat }\end{array}$ & - & - \\
\hline & Jumlah & 5 & $50 \%$ & Jumlah & 5 & $\begin{array}{l}50 \\
\%\end{array}$ \\
\hline
\end{tabular}

Berdasarkan tabel diatas, responden yang mengalami nyeri hebat turun menjadi nyeri sedang sebanyak 1 responden, responden yang mengalami nyeri berat turun menjadi nyeri sedang sebanyak 1 responden sedangkan responden yang mengalami nyeri berat turun menjadi nyeri ringan sebanyak 3 responden.

Tabel 3 tabulasi silang distribusi pemberian kompres hangat dan kompres air jahe terhadap low back pain

\begin{tabular}{llllll}
\hline No. & Kategori & \multicolumn{2}{l}{$\begin{array}{l}\text { Kompres } \\
\text { hangat }\end{array}$} & \multicolumn{2}{l}{$\begin{array}{l}\text { Kompres } \\
\text { air jahe }\end{array}$} \\
& & $\begin{array}{l}\text { Pre } \\
\text { tes }\end{array}$ & Post & $\begin{array}{l}\text { Pre } \\
\text { tes }\end{array}$ & Post \\
& & tes \\
\hline 1 & Nyeri ringan & - & - & - & 3 \\
2 & Nyeri sedang & 1 & 5 & - & 2
\end{tabular}




\begin{tabular}{llllll}
3 & Nyeri berat & 4 & - & 4 & - \\
4 & Nyeri hebat & - & - & 1 & - \\
& TOTAL & 5 & 5 & 5 & 5 \\
\hline
\end{tabular}

Hasil uji Mann whitney $\mathrm{p}=0.05$

Berdasarkan data dari tabel diatas dari 5 responden yang diberikan kompres hangat. Sebanyak 4 dari nyeri berat mengalami penurunan menjadi nyeri sedang. Sedangkan dari 5 responden yang diberikan kompres jahe sebanyak 3 responden dari nyeri berat mengalami penurunan menjadi nyeri ringan. Hasil uji statistik Mann whitney $(p=0.05)$ tidak signifikan yang artinya tidak ada perbedaan antara kompres hangat dan kompres air jahe

\section{PEMBAHASAN}

Dari tabel 3 dapat kita ketahui bahwa dari 10 responden yang diberikan intervensi kompres air hangat dan air jahe selama 2 minggu ( $4 \mathrm{x}$ pertemuan) bahwa total keseluruhan responden akibat nyeri akibat low back pain sebanyak 10 responden (100\%) yang diantaranya dibagi menjadi 2 kelompok yaitu kompres air hangat sebanyak 5 responden $(50 \%)$ sedangkan dari kompres air jahe sebanyak 5 responden (50\%). Bedasarkan hasil penelitian yang tersebut menunjukan bahwa kompres hangat dan kompres air jahe efektif dalam menurunkan skala nyeri yang ditimbulkan low back pain. Nilai signifikansi hasil uji statistic Mann Whitney dengan nilai $\mathrm{p}=0,05(\mathrm{p}<0,05)$, yang akhirnya memperoleh hasil bahwa tidak ada perbedaan yang signifikan antara kompres air hangat dan kompres air jahe terhadap skala nyeri low back pain. Menurut Hidayat (2008), kompres hangat yang menimbulkan sensasi hangat mampu menurunkan nyeri karena relaksasi yang ditimbulkan dari cairan hangat. Hal tersebut juga dinyatakan oleh Nyoman (2013), bahwa kandungan alami jahe yang memiliki sifat hangat dapat menimbulkan efek analgesic sehingga dapat menurunkan nyeri. Bila dikaitkan hasil penelitian dengan teori tersebut terdapat keselaran. Sekalipun dalam hasil statistic yang menunjukkan tidak ada perbedaan penurunan skala nyeri pada kompres hangat dan kompres jahe tetapi bila dilihat penurunan skala nyeri low back pain pada tabel 3 maka dapat terlihat bahwa kompres air jahe lebih efektif dalam menurunkan skala nyeri low back pain dari pada kompres air hangat. Pada kompres air hangat 4 responden yang mengalami skala nyeri berat menunjukan penurunan nyeri menjadi nyeri sedang, sedangkan pada kompres air jahe 1 responden yang mengalami nyeri hebat dan 4 responden mengalami nyeri berat seluruhnya mengalami penurunan skala nyeri yaitu menjadi nyeri sedang 2 orang dan nyeri ringan 3 orang. Dari data ini menunjukan bahwa kompres jahe lebih efektif dari pada kompres hangat. Hal ini dikarenakan kandungan alami pada jahe yang dapat menimbulkan rasa hangat pada kulit. Rasa hangat yang ditimbulkan oleh jahe bertahan lebih lama dikulit manusia dibandingkan dengan kompres air hangat. Rasa hangat yang ditimbulkan oleh kompres jahe menimbulkan efek relaksasi pada individu yang menyebabkan peredaran darah menjadi lancar sehingga dapat menurunkan intensitas nyeri yang dirasakan. Sehingga kelompok responden yang diberikan kompres jahe lebih banyak mengalami penurunan nyeri dibandingkan dengan kelompok responden yang diberikan kompres hangat. Hal ini juga didukung oleh jurnal penelitian menurut Henny (2018), dengan judul Kompres jahe berkhasiat dalam menurunkan intensitas nyeri pada lansia menyatakan bahwa kompres jahe lebih efektif dalam menurunkan skala nyeri berat sehingga seluruh responden menjadi skala nyeri ringan.

\section{SIMPULAN}

Skala nyeri responden low back pain sebelum dilakukan kompres hangat dan kompres air jahe di Panti Usiawan Surya Surabaya, mayoritas memiliki skala nyeri berat sebanyak 8 responden $(80 \%)$. Skala nyeri responden low back pain nyeri setelah dilakukan kompres hangat sebagian besar nyeri sedang sebanyak 4 responden $(40 \%)$ dan kompres air jahe sebagian besar memiliki skala nyeri sedang sebanyak 2 responden $(20 \%)$ responden dan nyeri ringan sebanyak 3 responden $(30 \%)$.

Tidak terdapat perbedaan antara kompres air hangat dan air jahe terhadap skala nyeri low back pain di Rumah Usiawan Panti Surya Surabaya yang ditunjukan dengan hasil uji statistic Mann-whitney $(p=0,05)$ atau H0 diterima. 
DAFTAR PUSTAKA

Abdullah, Mujianto. 2013. Cara Cepat Mengatasi 10 Besar Kasus Muskuloskeletal dalam Praktik Klinik Fisioterapi. Jakarta: Trans InfoMedia

AHCPR. 1992.Acute pain management: operative or medical procedure and trauma.http://www.ncbi.nlm.nih.gov/bo oks/bv.fcgi? diperoleh tanggal 12 Nopember 2017

Anugraheni V dan Wahyuningsih A. 2013. Efektifitas Kompres Hangat Dalam Menurunkan Intensitas Nyeri Dysmenorrhea Pada Mahasiswi Stikes RS Baptis Kediri. Jurnal STIKES. Vol 6

Astuti, Yuliana. 2011. Peningkatan Kedisiplinan Dan Prestasi BelajarMatematika Melalui Model Pembelajaran Probing-Prompting Dan Metode Pembelajaran Cooperative Script. Skripsi. Surakarta: FKIP UMS

Azizah, Lilik Ma' rifatul, 2011. Keperawatan LanjutUsia. Edisi 1. Yogyakarta: Grahallmu

Barbara, R., Hegner, Ehter, 2003. Asiten keperawatan suatu pendekatan proses keperawatan. Jakarta: Buku Kedokteran

Bartley, J. dan A. Jacobs. (2000). Effects of drying on flavour compounds in Australiangrown ginger (Zingiber officinale). Journal of the Science of Food and Agriculture. 80:209-215.

Bimariotejo. 2009. Low Back Pain (LBP). Diambil $20 \quad$ Nopember 2017 dariwww.backpainforum.com

Brunnner \& Suddarth. 2002. Buku Ajar keperawatan Medikal Bedah. (ed. 8). Jakarta: EGC

Dachlan L.M., 2009. Pengaruh Back Exercise Pada Nyeri PunggungBawah. Surakarta: Tesis Magister Kedokteran Keluarga Universitas Sebelas Maret.

Henny. 2018. Kompres Jahe Berkhasiat dalam Menurunkan Intensitas Nyeri pada Penderita Rheumatoid Arthritis. Jurnal Program Studi Ners, Universitas Sari Mutiara Indonesia

Hidayat, A.A. 2008. Praktikum Ketrampilan Dasar Praktik Klinik. Jakarta: Salemba Medika

Irwan Wirya, Margareth Duma Sari (2013). Pengaruh Pemberian Massase Punggung dan Teknik Relaksasi Nafas Dalam terhadap Penurunan Intensitas
NyeriPada Pada Pasien Post Appendiktomi. Jurnal Keperawatan HKBP Balige,Vol.1 No.1 diunduh dari http://www.akperhkbp.ac.id.

Juwita, Sandra. 2014. Pengaruh Derajat Depresi Dengan Intensitas Nyeri Kronik. KTI. Semarang: Fakultas Kedokteran Universitas Diponegoro

Kushariyadi. 2010. Asuhan Keperawatan Klien Lanjut Usia. Jakarta: Salmba Medika

Leach, MJ dan Kumar, S. 2008. The Clinical Effectiveness of Ginger (Xinger Officinale) in adults with Osteoarthtritis, International Journal Ofevidance Based Health Centre, Diakses 26 Nopember 2017, ProquestDatabase

Lewis, Sharon L et al. 2011. Medical Surgical Nursing Volume 1. United States America: Elsevier Mosby.

Malanga \& Nadler. 1999. Nonoperatif treatment of low back pain. Mayo Clinic Proceedings

Masyhurrosyidi $\mathrm{H}$, Kumboyono dan Utami YW. 2013. Pengaruh Kompres Hangat Rebusan Jahe terhadap tingkat nyeri subkutan dan kronis pada lanjut usia dengan osteoarthritis lutut di Puskesmas Arjuna Kecamatan Klojen Malang Jawa Timur. Program keperawatan. Malang: Fakultas Kedokteran Universitas Brawijaya.

Mujahidullah. Khalid, 2012. Keperawatan Geratrik, Yogyakarta: Pustaka Belajar

Nugroho, W. 2008. Keperawatan Gerontik. Jakarta: EGC

Nyoman, Nastiti \& Dewa. 2011. Pengaruh kombinasi ekstrak temulawak, jahe, kedelai dan kulit udang terhadap fungsi hati dan ginjal dibandingkan dengan natrium diklofenak pada penderita Osteoartritis.

Price, A.S. \& Wilson ML, 2005, Patofisiologi: konsep klinis prosesproses penyakit (Pathophysiology: clinical consept of disease processes), eds. Hartanto, $H$, dkk. Jakarta: EGC

Primana, D.A. 2006. Fleksibilitas Sendi Lanjut Usia Pada Berbagai Kompensasi Tubuh. Jurnal Knowledge management (JKM).

Rahim, A. H. (2013). Terapi konservatif untuk low back 
pain.http://www.jamsostek.co.id/content file/terapi.pdf

Samara, 2005. Duduk Statis sebagai Faktor Resiko Terjadinya Nyeri Punggung Bawah Pada Pekerja Perempuan. Jurnal Universitas Medicina.

Shocker, M. (2008). Pengaruh Stimulus Kutaneus: Slow-Stroke Back Massage terhadap Intensitas Nyeri Osteoarthritis.

Vicky. 2006. Back and Neck Related Condition: Low Back Pain. Diunduh tanggal 25 Juni 2018

Yuliana. 2011. Low back pain. Cermin Dunia Kedokteran 38(4): 273. 